\title{
The influence of riparian woodlands on the thermal conditions of small lowland streams during the summer
}

\author{
Maksym Laszewski ${ }^{1 *}$, Wojciech Kiryła ${ }^{2}$ \\ ${ }^{1}$ University of Warsaw, Faculty of Geography and Regional Studies, Department of Hydrology, ul. Krakowskie Przedmieście 30, 00-927 \\ Warszawa, Poland; ${ }^{2}$ Institute of Geodesy and Cartography, Remote Sensing Centre, ul. Kaczmarskiego 27, 02-679 Warszawa, Poland \\ *Tel. +48 601189 824, e-mail: m.laszewski@uw.edu.pl
}

\begin{abstract}
Riparian woodlands significantly affect the water quality of streams and rivers. Thus, we examined whether the presence of woodlands in riparian buffer zones also impacts the thermal characteristics of lowland streams during the summer. Water temperature data were recorded with digital temperature loggers located in eight quasi-natural sites across the Garwolin Plain in central Poland. The mean, maximum, minimum, and mean daily range parameters were calculated for the whole study period from July to September 2017 with a $30 \mathrm{~min}$. resolution. The percentage of woodlands in the catchment area and buffer zone along the streams was estimated based on satellite images from the Sentinel-1 and Sentinel-2 missions. The Random Forest method was used in the classification process with an accuracy of $96 \%$. The similarity of measurement sites in terms of water temperature was determined using cluster analysis (Ward method), while a Spearman correlation coefficient was applied to compare thermal parameters with the percentage of woodland areas.

The results indicate that water temperature patterns across the measurement sites varied, with mean temperatures ranging from $14.4^{\circ} \mathrm{C}$ in site $\mathrm{T} 8$ to $16.3^{\circ} \mathrm{C}$ in site $\mathrm{T} 1$. Furthermore, the correlation analysis confirmed our hypothesis that the presence of woodland areas does not significantly alter the thermal parameters of lowland streams. Moreover, the cluster analysis showed that sites with significantly different percentages of woodland areas were closely linked due to the similar distributions of water temperature values. However, it must be emphasised that the lack of riparian woodlands in buffer zones does not exclude the presence of shade associated with shrubs and grasses, as well as aquatic plants. In consequence, more advanced indicators of riparian shade, such as vegetation mapping using unmanned aerial vehicle (UAV) or hemispherical photography, should be used for small lowland streams.
\end{abstract}

Keywords: water temperature, satellite images, woodland areas, lowland streams

\section{Introduction}

The issues concerning the impact of woodland areas on the quantity and quality of water resources occupy an important place in the hydrological literature and are characterised by a large diversity of research topics (Pierzgalski 2008). Most attention has been given to the retention function of forests, which is important in shaping drainage outflow (Brown et al. 2013) and mitigating the negative effects of extreme events - floods and low water levels (Robinson et al. 2003; Lin, Wei 2008). The presence of woodland areas in a catchments has been shown to determine the intensity of evapotranspiration (Peel et al. 2010), whilst deforestation and tree stand degradation (as a result of pest gradation) have been found to influence the chemical composition of water, including the concentration of nitrates (Kosmowska et al. 2015; Żelazny et al. 2017). The presence of woodland areas also strongly affects the local microclimate, which is responsible for shaping the heat energy budget of river waters and, as a result, their temperature (Caissie 2006). However, water temperature is one of the most important water quality parameters of fundamental ecological importance; its maximum values determine the geographical ranges of individual fish and invertebrate species, seasonal and daily variations determine bioenergetics and the rate of physiological processes, whilst the time when specific values occur

Received: 26.06.2018, reviewed: 6.08.2018, accepted: 20.08.2018. 
during the year is important in the context of migration and spawning (Benjamin et al. 2016).

Studies of the impact of woodland areas on the thermal system of watercourses focused on comparing selected thermal traits at measuring sites shaded by trees and those lacking shade located along the longitudinal profile of a single watercourse (Malcolm et al 2004; Imholt et al. 2013a), as well as within a larger number of catchments (Kristensen et al. 2015). Issues relating to the impact of deforestation (Stott, Marks 2000) and forest fires (Mahlum et al. 2011) on changes in the thermal characteristics of river waters were also discussed. The percentage of woodland areas was also included as an explanatory variable in statistical models linking landscape metrics to thermal parameters (Hrachowitz et al. 2010; Imholt et al. 2013b). It should be emphasised that the empirical data of most studies concerned mountain or upland rivers, characterised by a steep slope and lack of aquatic macrophytes.

The purpose of this article is to assess the impact of woodland areas on the water temperature of lowland watercourses. On the basis of our own measurements of water temperature and the identification of woodland areas using satellite image classification, we examined whether the percentage of woodland areas is reflected in the thermal characteristics of watercourses during the summer. For the purpose of the study, eight lowland catchments located in central Poland were compared, characterised by a diversified level of afforestation of the catchment areas and riparian zones.

\section{Study area}

Water temperature of watercourses in the hydrographic network of the middle Świder River, a lowland tributary of the Vistula River, with a length of $99 \mathrm{~km}$ and a catchment area of $1160.7 \mathrm{~km}^{2}$, were measured. The catchments at the end of the measurement sites are located within the flat, fluvial Garwolin Plain in which the soils are dominated by post-glacial sands, gravels and boulder clay; their absolute height varies from 117 to $178 \mathrm{~m}$. The area is located in a temperate climate zone having transitional features, with an average annual air temperature of approximately $8-9^{\circ} \mathrm{C}$ and an annual rainfall of approximately $500-550 \mathrm{~mm}$. The river channels are characterised by a straight or winding course, small depth (maximum $80-100 \mathrm{~cm}$ ) and a width of 1-2 m, on an average. In some sections, ash-alder Fraxino-Alnetum and willow-poplar Salici-Populetum forests mainly grow along the banks. In addition to the riverine forests, the forest assemblage of the catchment is formed by dense complexes of mixed conifer forests Querco roboris-Pinetum, consisting mainly of Scots pine (Pinus sylvestris L.), birch (Betula L.) and oak (Quercus L.). The study area has a small degree of urbanisation - the percentage of anthropogenic areas is from $0.1 \%$ in the catchment of $\mathrm{T} 6$ to $7.0 \%$ in $\mathrm{T} 4$.

\section{Methods and materials}

\subsection{Field measurements}

Water temperature was measured from July 1 to September 30, 2017. This range was aimed at excluding the temporal variability of the degree of shading associated with the presence of conifers and deciduous trees - it was assumed that as of July, tree leaves are fully developed, which allowed us to distinguish one class, regardless of the type of trees. The measurements were taken with HOBO UA001-08 Pendant digital water temperature recorders (Onset Computer Corporation) with an accuracy of $0.4^{\circ} \mathrm{C}$ and a resolution of $0.01^{\circ} \mathrm{C}$. The devices were placed in the current in perforated shields attached to boulders or wooden logs and stakes. The measurement sites were located in watercourses that ensured a stable water flow during the summer period as well as in those characterised by a varied level of afforestation in the buffer zones (riparian zones) (Figure 1). Four basins were selected to represent first-order watercourses, whose area did not exceed $10 \mathrm{~km}^{2}$, and four catchments were selected with a larger area (from 18.5 to $38.7 \mathrm{~km}^{2}$ ), representing second-order watercourses (Table 1).

\subsection{Assessment of the percentage of tree cover}

The identification of woodland areas was based on the classification of satellite images obtained from the Sentinel-1 and Sentinel-2 satellites. In the case of Sentinel-1, radar data (type $\mathrm{C}$ wave) images recorded between 1-31 May 2017, 1-30 June and 1-31 October 2017 were used (a

Table 1. Characteristics of water temperature measurements sites

\begin{tabular}{crrrrrr}
\hline \hline P & $\begin{array}{c}\mathrm{A} \\
{\left[\mathrm{km}^{2}\right]}\end{array}$ & $\begin{array}{c}\mathrm{L} \\
{[\mathrm{km}]}\end{array}$ & $\begin{array}{c}\mathrm{W}: \mathrm{D} \\
{[-]}\end{array}$ & $\begin{array}{c}\mathrm{W} 1 \\
{[\%]}\end{array}$ & $\begin{array}{r}\mathrm{W} 2 \\
{[\%]}\end{array}$ & $\begin{array}{c}\mathrm{W} 3 \\
{[\%]}\end{array}$ \\
\hline $\mathrm{T} 1$ & 23.8 & 9.2 & 15.7 & 33.4 & 24.3 & 0.0 \\
\hline $\mathrm{T} 2$ & 7.5 & 5.1 & 11.3 & 29.1 & 44.4 & 67.8 \\
\hline T3 & 19.0 & 6.4 & 7.5 & 50.8 & 61.5 & 15.8 \\
\hline T4 & 9.3 & 5.4 & 10.3 & 12.7 & 9.7 & 0.0 \\
\hline T5 & 38.7 & 11.9 & 32.8 & 29.3 & 30.9 & 96.5 \\
\hline T6 & 8.4 & 5.6 & 6.9 & 13.1 & 9.3 & 52.1 \\
\hline T7 & 18.5 & 6.1 & 10.2 & 57.1 & 43.2 & 0.0 \\
\hline T8 & 9.1 & 5.1 & 10.2 & 57.9 & 48.1 & 1.4 \\
\hline \hline
\end{tabular}

Explanations: $\mathrm{P}$ - measurement profile, $\mathrm{A}$ - catchment area, $\mathrm{L}$ - distance from the source, W:D - width:depth ratio, W1 - percentage of woodland area in the catchment area, W2 - percentage of woodland area in the buffer zone upstream to the source, W3 - percentage of woodland area in the buffer zone $1 \mathrm{~km}$ upstream 
separate median mosaic of images for VH and VV polarisation was made for each month). In the case of optical data from Sentinel-2 (with a radiometric resolution of 12 bits), the display from 17 October 2017 was used, which was characterised by a lack of cloud cover ( $0 \%$ cloud cover), facilitating the distinction of woodland from crop and meadow vegetation. For the purpose of the classification, channels 2 , $3,4,8$ (with a resolution of $10 \mathrm{~m}$ ) and 12 (with a resolution of $20 \mathrm{~m}$ ) were selected. The atmospheric correction of the Sentinel-2 imaging was performed automatically in dedicated Sen2Cor 2.4.0 software. Then, the SNAP 6.0.0 program was used to resample the pixels from the data to a resolution of $10 \mathrm{~m}$ and cut to the border of the analysed area. The final stage preceding classification was the combination of Sentinel-1 radar data with Sentinel-2 optical data; this process leads to an overall increase in the accuracy of the classification algorithm (Bagan et al. 2012).

The land cover classification distinguished two classes, that is, areas with and without tree cover, in the EnMap Box 2.2.1 program. The Random Forest classifier (RF - algorithm of random decision trees) was selected as the classification algorithm, which allows the relatively best results to be obtained compared to other algorithms, for example, SVM - Support Vector Machine (Dalponte et al. 2012; Wietecha et al. 2017). The total accuracy of the classification was $94.9 \%$, the accuracy of the producer was $91.4 \%$, the accuracy of the user $90.9 \%$ for the woodland and $96.4 \%$ for non-woodland areas and the Kappa factor was $87.3 \%$.

The classification results allowed calculations to be made of the percentage of woodland areas within the total catchment area (Ptak 2017), a 50-m wide buffer zone delineated on both banks upstream to the sources, as well as on a 1-km section upstream from the measurement site, similar to Hrachowitz et al. (2010). Spatial analyses were performed in the ESRI ArcMap 10.2.2 program.

\subsection{Statistical methods}

In order to characterise the thermal conditions during the analysed period, basic statistical parameters were determined for all measurement sites: average temperature, maximum temperature, minimum temperature and average daily range. Verifying the statistical significance of differences in the temperature distribution between the measurement sites required

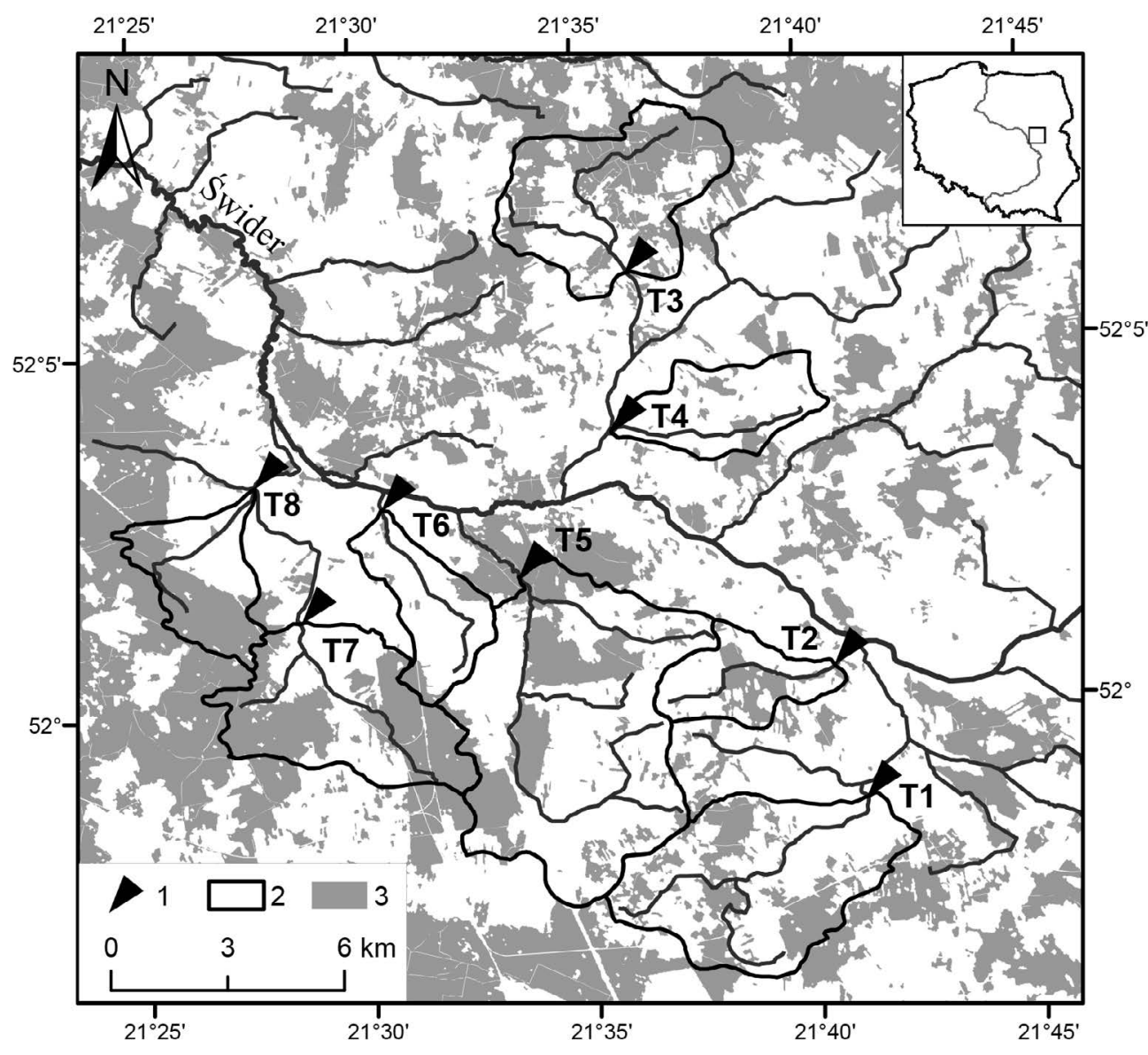

Figure 1. Locations of measurement sites on the background of forested and woodland areas

Explanations: 1 - measurement sites, 2 catchment area, 3 - forest and woodland areas 
a)

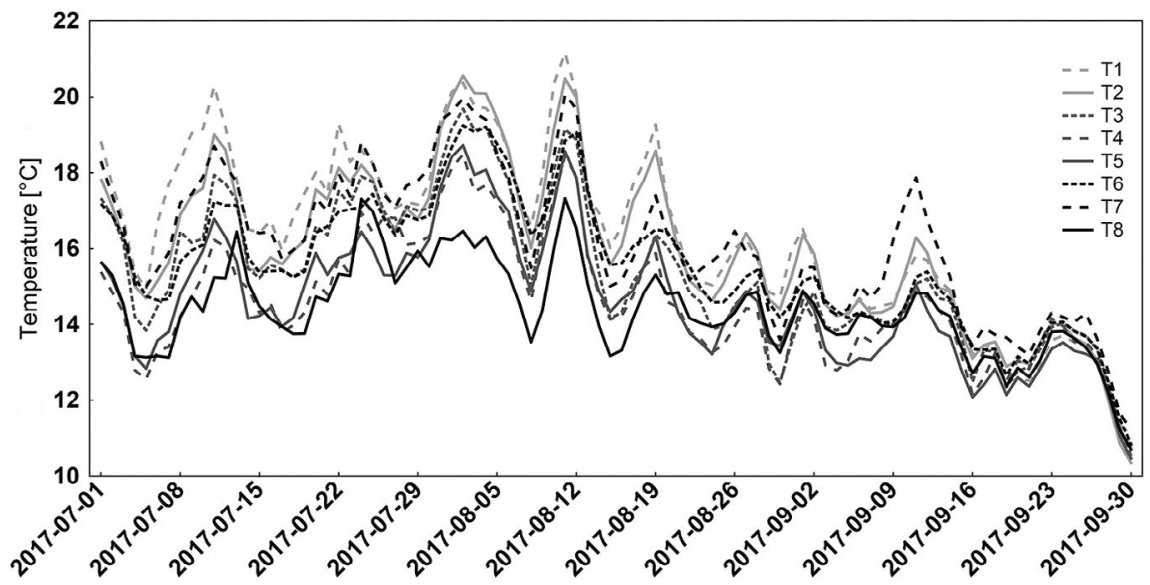

b)

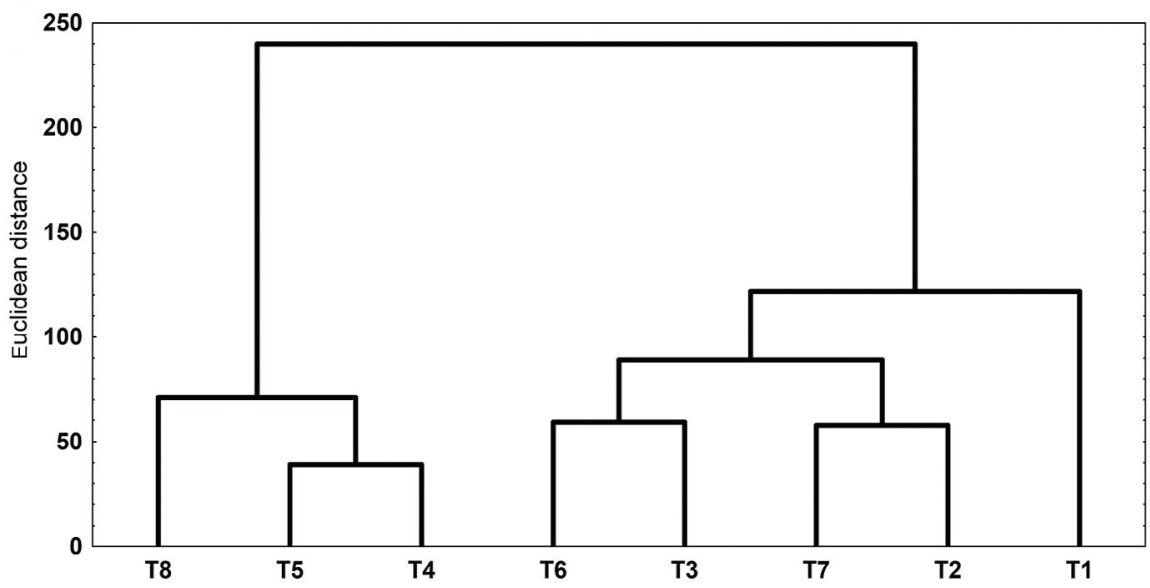

Figure 2. Mean daily water temperature patterns in the measurement sites (a) and dendrogram showing the results of grouping by Ward method (b) the use of the Kruskal-Wallis nonparametric test and Dunn's multiple vertical rank test (post-hoc); the statistically significant threshold was assumed at $p=0.05$. To isolate the sites with the greatest similarity in terms of water temperature variability, the Ward agglomeration method was used - the Euclidean distance was assumed as the measure of the similarity of the sites. Relationships between the percentage of woodland area (W1, W2 and W3) and the thermal parameters were determined using the Spearman rank correlation coefficient.

\section{Results}

In the analysed period, the water temperature of lowland watercourses was characterised by a marked spatial differentiation (Figure 2a). Average water temperature values from July to September reached from $14.4^{\circ} \mathrm{C}$ at $\mathrm{T} 8$ to $16.3^{\circ} \mathrm{C}$ at $\mathrm{T} 1$ (Table 2 ). Even greater spatial variability was noted for the absolute maximum water temperature, which ranged from $18.8^{\circ} \mathrm{C}$ at $\mathrm{T} 8$ to even $25.9^{\circ} \mathrm{C}$ at $\mathrm{T} 1$. All sites had similar values for minimum water temperature, from $9.0^{\circ} \mathrm{C}$ in $\mathrm{T} 7$ to $10.5^{\circ} \mathrm{C}$ in $\mathrm{T} 6$. The daily temperature range of the water in the study period reached, on an average, from $1.0^{\circ} \mathrm{C}$ in $\mathrm{T} 6$ to $4.2^{\circ} \mathrm{C}$ in $\mathrm{T} 1$. The result of the Kruskal-Wallis test indicates that the differences between the medians of water temperature distribution within the study sites were statistically significant $(\mathrm{p}<0.05)$; the post-hoc test, however, proves the lack of statistical significance between the medians of the temperature distribution within sites T1, T2 and T7, as well as between sites T4 and T5 ( $\mathrm{p}>0.05)$. The correlation analysis showed that none of the metrics showing the extent of afforestation of the catchment area and buffer zones (W1, $\mathrm{W} 2$ and W3) was related in a statistically significant way to the thermal parameters (Table 3).

The Ward agglomeration method allowed two-point clusters to be distinguished (Fig. 2b). The first includes sites T4, $\mathrm{T} 5$ and $\mathrm{T} 8$, representing watercourses characterised by the lowest average values and relatively low maximum water temperature values, not exceeding $20.5^{\circ} \mathrm{C}$ (Fig. 2b). The second cluster included the remaining sites T1, T2, T3, T6 
Table 2. Thermal parameters of water in the investigated sites

\begin{tabular}{ccccc}
\hline \hline P & $\begin{array}{c}\text { T_avg } \\
{\left[{ }^{\circ} \mathrm{C}\right]}\end{array}$ & $\begin{array}{c}\text { T_max } \\
{\left[{ }^{\circ} \mathrm{C}\right]}\end{array}$ & $\begin{array}{c}\text { T_min } \\
{\left[{ }^{\circ} \mathrm{C}\right]}\end{array}$ & $\begin{array}{c}\text { T_range } \\
{\left[{ }^{\circ} \mathrm{C}\right]}\end{array}$ \\
\hline $\mathrm{T} 1$ & 16.3 & 25.9 & 9.6 & 4.2 \\
\hline $\mathrm{T} 2$ & 16.0 & 22.4 & 9.4 & 2.4 \\
\hline $\mathrm{T} 3$ & 15.4 & 20.9 & 9.7 & 2.3 \\
\hline $\mathrm{T} 4$ & 14.6 & 20.5 & 10.0 & 2.7 \\
\hline $\mathrm{T} 5$ & 14.6 & 20.4 & 9.6 & 2.5 \\
\hline T6 & 15.6 & 19.6 & 10.5 & 1.0 \\
\hline T7 & 16.1 & 21.5 & 9.0 & 2.9 \\
\hline T8 & 14.4 & 18.8 & 10.0 & 2.2 \\
\hline \hline
\end{tabular}

Explanations: $\mathrm{P}$ - measurement profile, $\mathrm{T}$ avg - mean temperature, $\mathrm{T}$ max - maximum temperature, $T \_$min - minimum temperature, $T_{-}$range - mean daily range

Table 3. Spearman correlation coefficients between water temperature parameters and contribution of woodland area (metrics W1, $\mathrm{W} 2$, and W3). Statistically significant correlation values are bolded $(p<0,05)$

\begin{tabular}{rccccccc}
\hline \hline & $\begin{array}{c}\mathrm{T}_{-} \\
\text {avg }\end{array}$ & $\begin{array}{c}\mathrm{T}_{-} \\
\max \end{array}$ & $\begin{array}{c}\mathrm{T}_{-} \\
\min \end{array}$ & $\begin{array}{c}\mathrm{T}_{-} \\
\text {range }\end{array}$ & $\mathrm{W} 1$ & $\mathrm{~W} 2$ & $\mathrm{~W} 3$ \\
\hline T_avg & 1.00 & & & & & & \\
\hline T_max & $\mathbf{0 . 8 3}$ & 1.00 & & & & & \\
\hline T_min & -0.57 & $\mathbf{- 0 . 7 2}$ & 1.00 & & & & \\
\hline T_range & 0.51 & $\mathbf{0 . 7 1}$ & -0.64 & 1.00 & & & \\
\hline $\mathrm{W} 1$ & -0.01 & -0.02 & -0.31 & 0.02 & 1.00 & & \\
\hline $\mathrm{W} 2$ & -0.19 & 0.07 & -0.34 & -0.19 & $\mathbf{0 . 7 1}$ & 1.00 & \\
\hline $\mathrm{W} 3$ & -0.27 & -0.29 & 0.02 & -0.56 & -0.22 & 0.15 & 1.00 \\
\hline \hline
\end{tabular}

and $\mathrm{T} 7$, which were characterised by higher average values - from $15.4^{\circ} \mathrm{C}$ to $16.3^{\circ} \mathrm{C}$ - and maximum values - from $19.6^{\circ} \mathrm{C}$ to $25.9^{\circ} \mathrm{C}$. Within the second cluster, attention is drawn to site $\mathrm{T} 1$, which has the highest water temperature average and maximum value, as well as the highest daily variation, with an average range of $4.2^{\circ} \mathrm{C}$. Within the $\mathrm{T} 4, \mathrm{~T} 5$ and $\mathrm{T} 8$ cluster, the percentage of woodland area in the buffer zones was varied and reached from $0.0 \%$ to $96.5 \%$ over the $1-\mathrm{km}$ distance and from $9.7 \%$ to $48.1 \%$ in the section upstream to the sources. A similar situation exists in the case of warmer watercourses (T1, T2, T3, T6 and T7), where the percentage of woodland area was between $0.0 \%$ and $67.8 \%$ along the $1-\mathrm{km}$ section and from $9.3 \%$ to $61.5 \%$ in the seg- ments upstream to the sources. As a result, sites having a similar degree of riparian zone afforestation, as in the case of $\mathrm{T} 7$ and T8, were characterised by different thermal conditions and were included in separate clusters (Figure 2b).

\section{Summary and conclusions}

As documented in the literature, the heat energy budget of flowing waters is shaped mainly by radiation energy flows, primarily short-wave solar radiation and long-wave radiation (Caissie 2006). Covering the water surface with trees and shrubs has a significant impact on its modification - it has been proven that as a result of absorbing and reflecting solar radiation, vegetation significantly reduces maximum temperature values (Imholt et al. 2013a). Dense tree crowns also limit the night radiation of heat from water and emit their own long-wave radiation, causing an increase in the minimum temperature and, consequently, a reduction in daily fluctuations (Brown et al., 2010). However, in the case of small lowland watercourses, the percentage of tree-lined areas designated within their catchments and riparian zones based on satellite imaging did not exhibit a clear link to the values of individual thermal parameters, which was indicated by the obtained values of the rank correlation coefficients. Both the measurement sites characterised by a significant percentage of trees in the riparian zone as well as those completely devoid of shading were found to have similar thermal conditions in the study period. For example, despite the considerably different degree of riparian zone afforestation at sites $\mathrm{T} 4$ and $\mathrm{T} 5$, very similar thermal parameter values were found. The case of sites $\mathrm{T} 2$ and $\mathrm{T} 7$ was analogous, they were characterised by a similar mean, maximum and minimum water temperature values. It should be emphasised that the lack of woodland area did not preclude the water surface from being shaded against solar radiation; the greater availability of light (because of the lack of shade from tree crowns) resulted in an intensive development of shrubs, grasses and perennials along the banks, which almost completely covered the water surface. Additional shading, especially in the case of site $\mathrm{T} 4$ and $\mathrm{T} 8$, was also provided by aquatic macrophytes - locally, the channel of these watercourses was heavily overgrown by plant communities of European bur-reed (Sparganium emersum L.), arrowhead (Sagittaria sagittifolia L.), reed canary grass (Phalaris arundinacea L.) and phragmites (Phragmites australis (Cav.) Trin. ex Steud.). It is worth noting that the presence of compact macrophyte communities, as Willis et al. have shown (2017) with the example of Big Springs Creek in the United States, causes a reduction in maximum water temperature.

With reference to the above findings, it should be noted that the actual degree of shading of small lowland watercourses is impossible to quantify numerically using satellite 
data, even using images of woodland areas from the Sentinel mission, characterised by high temporal (affecting the currentness of the photos) and spatial (pixel $10 \mathrm{~m}$ ) resolutions. Such an assessment requires the use of more accurate methods, taking into account the said channel cover by shrubs and grasses along the banks, as well as aquatic vegetation. The use of unmanned aerial vehicles (UAVs), which are playing an increasingly important role in researching forest and wooded areas (Zmarz 2014), seems to be the optimal solution for mapping the cover of a watercourse channel. An auxiliary method may also be used for the field verification of shading, for example, using hemispherical photographs taken from the level of the water surface (Bartnik, Moniewski 2011).

The conclusions presented do not contradict the research results of other authors who demonstrated a moderating influence of afforestation in catchment areas and riparian zones on the water temperature of watercourses in the summer period (including Hrachowitz et al. 2010; Imholt et al. 2013a; Ptak 2017). The research mentioned usually concerned larger watercourses (with catchment areas ranging from several dozen to several hundred square kilometre), whose temperature, mainly due to the longer exposure of water to meteorological conditions as well as to wider riverbeds, is more dependent on the extent of tree cover over the water surface. In the case of small, narrow watercourses, besides the shading associated with the presence of shrubs and grasses (Beschta 1997), the groundwater inflow (Poole, Berman 2001) is also important in shaping water temperature. This fact indicates the need to be careful in applying the metrics used in statistical models previously identified for watercourses having different abiotic parameters.

\section{Conflict of interest}

The authors declare no potential conflicts of interest.

\section{Acknowledgment and source of funding}

The research was funded by the University of Warsaw (DSM: 501-D119-86-0115500-05).

\section{References}

Bagan H., Kinoshita T., Yamagata Y. 2012. Combination of AVNIR2, PALSAR, and polarimetric parameters for land cover classification. IEEE Transactions on Geoscience and Remote Sensing 50(4): 1318-1328. DOI 10.1109/TGRS.2011.2164806.

Benjamin J.R., Heltzel J.M., Dunham J.B., Heck M., Banish N. 2016. Thermal Regimes, Nonnative Trout, and Their Influences on Native Bull Trout in the Upper Klamath River Basin, Oregon. Transactions of the American Fisheries Society 145(6): 1318-1330. DOI 10.1080/00028487.2016.1219677.
Beschta R.L. 1997. Riparian Shade and Stream Temperature: An Alternative Perspective. Rangelands 19(2): 25-28.

Brown A.E., Western A.W., McMahon T.A., Zhanga L. 2013. Impact of forest cover changes on annual streamflow and flow duration curves. Journal of Hydrology 483: 39-50. DOI 10.1016/j.jhydrol.2012.12.031.

Brown L.E., Cooper L., Holden J., Ramchunder J. 2010. A comparison of stream water temperature regimes from open and afforested moorland, Yorkshire Dales, northern E n gland. Hydrological Processes 24(22): 3206-3218. DOI 10.1002/hyp.7746.

Bartnik A., Moniewski P. 2011. River Bed Shade and its Importance in the Process of Studying of the Fundamental Physico-Chemical Characteristics of Small River Waters. Contemporary Problems of Management and Environmental Protection 7: 137-149.

Caissie D. 2006. The thermal regime of rivers: a review. Freshwater Biology 51:1389-1406.DOI 10.1111/j.1365-2427.2006.01597.x.

Dalponte M., Bruzzone L., Gianelle D. 2012. Tree species classification in the Southern Alps based on the fusion of very high geometrical resolution multispectral/hyperspectral images and LiDAR data. Remote Sensing of Environment 123 : 258-270. DOI 10.1016/j.rse.2012.03.013.

Hrachowitz M., Soulsby C. Imholt C. 2010. Thermal regimes in a large upland salmon river: a simple model to identify the influence of landscape controls and climate change on maximum temperatures. Hydrological Processes 24(23): 3374 3391. DOI 10.1002/hyp.7756.

Imholt C., Soulsby C., Malcolm I.A., Gibbins C.N. 2013a. Influence of contrasting riparian forest cover on stream temperature dynamics in salmonid spawning and nursery streams. Ecohydrology 6(3): 380-392. DOI 10.1002/eco.1291.

Imholt C., Soulsby C., Malcolm I.A., Hrachowitz M., Gibbins C.N., Langan S., Tetzlaff D. 2013b. Influence of scale on thermal characteristics in a large montane river basin. River Research and Applications 29(4): 403-419. DOI 10.1002/rra.1608.

Kosmowska A, Żelazny M., Małek S., Siwek J.P. 2015. Wpływ wylesień na krótkoterminowe zmiany składu chemicznego wody w zlewni Potoku Malinowskiego (Beskid Śląski). Sylwan 159(9): 778-790.

Kristensen P.B., Kristensen E.A., Riis T., Alnoee A.B., Larsen S.E., Verdonschot P.F.M., Baattrup-Pedersen A. 2015. Riparian forest as a management tool for moderating future thermal conditions of lowland temperate streams. Inland Waters 5(1): 27-38. DOI 10.5194/hessd-10-6081-2013.

Lin Y., Wei X. 2008. The impact of large-scale forest harvesting on hydrology in the Willow watershed of Central British Columbia. Journal of Hydrology 359(1-2): 141-149. DOI 10.1016/j. jhydrol.2008.06.023.

Mahlum S.K., Eby L.A., Young M.K., Clancy C.G. Jakober M. 2011. Effects of wildfire on stream temperatures in the Bitterroot River Basin, Montana. International Journal of Wildland Fire 20: 240-247. DOI 10.1071/WF09132.

Malcolm I.A., Hannah D.M., Donaghy M.J., Soulsby C. Youngson A.F. 2004. The influence of riparian woodland on the spatial and temporal variability of stream water temperatures in an 
upland salmon stream. Hydrology and Earth System Science 8(3): 449-459. DOI 10.5194/hess-8-449-2004.

Peel M.C., McMahon T.A., Finlayson B.L. 2010. Vegetation impact on mean annual evapotranspiration at a global catchment scale. Water Resources Research 46, W09508. DOI 10.1029/2009WR008233.

Pierzgalski E. 2008. Relacje między lasem a wodą - przegląd problemów. Studia i materiały Centrum Edukacji PrzyrodniczoLeśnej w Rogowie 10(2): 13-23.

Poole G.C., Berman C.H. 2001. An ecological perspective on instream temperature: natural heat dynamics and mechanisms of human-caused thermal degradation. Environmental Management 27(6): 787-802.

Ptak M. 2017. Wpływ zalesienia zlewni na temperaturę wody w rzece. Leśne Prace Badawcze 78(3): 251-256. DOI 10.1515/ frp-2017-0028.

Robinson M., Cognard-Plancq A.L., Cosandey C., David J., Durand P., Fuhrer H.W. Hall R., Hendriques M.O., Marc V., McCarthy R., McDonnell M., Martin C., Nibset T., O’Dea P., Rodgers M., Zollner A. 2003. Studies of the impact of forests on peak flows and baseflows: a European perspective. Forest Ecology and Management 186(1-3): 85-97. DOI 10.1016/ S0378-1127(03)00238-X.

Stott T., Marks S. 2000. Effects of plantation forest clearfelling on stream temperatures in the Plynlimon experimental catchments, mid-Wales. Hydrology and Earth System Sciences 4(1): 95-104.

Wietecha M., Modzelewska A., Stereńczak K. 2017. Wykorzystanie lotniczej teledetekcji hiperspektralnej w klasyfikacji gatunkowej lasów strefy umiarkowanej. Sylwan 161(1): 3-17.

Willis A.D., Nichols A.L., Holmes E.J., Jeffres C.A., Fowler A.C., Babcock C.A., Deas M.L. 2017. Seasonal aquatic macrophytes reduce water temperatures via a riverine canopy in a spring-fed stream. Freshwater Science 36(3): 508-522. DOI 10.1086/693000.

Zmarz A. 2014. UAV - a useful tool for monitoring woodlands. Miscellanea Geographica 18(2): 46-52. DOI 10.2478/ mgrsd-2014-0006.

Żelazny M., Siwek J.P., Fidelus J., Stańczyk T., Siwek J., Rutkowska A., Kruk P., Wolanin A., Jelonkiewicz Ł. 2017. Wpływ wiatrołomu i degradacji drzewostanu na zróżnicowanie chemizmu wód w zlewni Potoku Kościeliskiego w obszarze Tatrzańskiego Parku Narodowego. Sylwan 161(1): 27-33.

\section{Author's contribution}

M.Ł. - concept, preparing the data, statistical analysis, interpreting the results, preparing the manuscript, literature review; W.K. - preparing the data, preparing the manuscript. 